\title{
Explaining inter-ethnic harmony in Enugu city, South-eastern Nigeria, 1970-2003
}

\section{Akachi Odoemene and Olufemi B. Olaoba ${ }^{\star}$}

\begin{abstract}
Ethnicity is a prominent feature in Nigeria's socio-economic environment and is fervently exhibited within the context of the 'indigene-settler dichotomy'. As this encourages exclusivism, it has been a major factor responsible for violent conflicts across the country. While many urban spaces in the country have witnessed such conflicts, a few have not. This study examines the indigene-settler inter-relations in Enugu to determine why and how the city sustained ethnic coexistence, cooperation and harmony since the end of the civil war (19671970). It demonstrates how, while ethnic attachment appeared to be strong, and while conflicts and occasional tensions did occur in the city, inter-ethnic relationships were cordial and symbiotic. It further identifies and interrogates cogent factors responsible for this trend. The paper argues that the constructive
\end{abstract}

* Dr Odoemene is a lecturer in the Department of History and International Relations, Redeemer's University of Nigeria, and currently a resident Research Fellow of the Irmgard Coninx Stiftung at the Social Science Research Centre, Berlin, Germany.

Dr Olaoba is a Senior Lecturer, and teaches African history and traditional conflict management and peacebuilding processes at the Institute of African Studies, University of Ibadan, Nigeria. 


\section{Akachi Odoemene and Olufemi B. Olaoba}

management of ethnic conflicts, as demonstrated in the city, could be efficient and productive. Despite optimism in Enugu's peaceful condition, however, it concludes that potential complications could emanate, as the factors responsible for Enugu's condition are amenable to change. Both primary and secondary sources (eighty-six in-person interviews, twelve focus group discussions, archival and secondary materials) were used within a multi-disciplinary framework.

\section{Introduction}

Relations between people of different ethno-cultural backgrounds are crucial concerns in the world, as conflicts, which naturally emanate from such relations, are important issues that impede effective interactions and social harmony. Ethnicity is a very powerful force in the socio-economic politics of Nigeria, and is more fervently exhibited within the 'indigene-settler dichotomy' (Odoemene 2008). This sharp division results both from the awareness of indigenes (hosts) and settlers (strangers) that they are different, and from the labelling of 'settlers' by 'indigenes' (Ibeanu and Onu 2001). Indeed, the indigene-settler question in Nigeria remains a contentious issue in accessing land, education, employment, political prospects and other socio-economic opportunities. Due to its exclusionary nature, it has been the root of many conflicts in the country.

Consequently, ethnic identity in Nigeria has profound consequences for the bearer's physical safety, political status and economic prospects (Agbese 2001; Albert 1993a; International IDEA 2000; Nnoli 1978; Otite 2000; Osaghae 1994; Ukiwo 2005). This is especially so for many millions of Nigerian citizens who have to live and work in inter-ethnic contexts. Obviously, a major social and political problem Nigeria faced in the preceding century and will continue to face in this twenty-first century is ethnicity (Agbese 2001).

The indigene-settler dichotomy, which is a nationwide phenomenon, has largely acquired acceptability all over Nigeria. The concept of 'indigeneship' remains very strong and viable in the country, as social spaces, even cities, are identified as 'belonging to' particular ethnic groups. As Plotnicov (1972:1-2) notes, 'Owners of the land' is a phrase widely employed in Nigeria to designate the 'indigenes' (natives) of an area, even when they are politically subordinate 
there; while 'strangers' (settlers), the paired contrasting term, covers people of alien origin who are permanently settled among these 'indigenes'. An attempt to clarify any of the two concepts, however, implies a simultaneous engagement with the other. Mamdani (1998:1) aptly captures this relationship: 'The settlernative question is a political question. It is also a historical question. Settlers and natives belong together. You cannot have one without the other for it is the relationship between them that makes one a settler and the other a native'.

The question concerning who 'indigenes' or 'settlers' are falls within the ambit of identity. This is a domain of exclusion and permanent contestation. This is so because the distinction between these groups is used for exclusionary purposes: 'indigenes' seek the exclusion of those categorised as 'settlers', while those being excluded on the ground of 'settlership' seek equity and contest their exclusion on grounds of citizenship of the Nigerian State (Egwu 2005:12). Thus, the 'indigene' and 'settler' syndrome in Nigeria is fast hardening into a theory of ethnic exclusiveness and exclusion. Nonetheless, apart from being a constitutive component of inter-group politics, ethnicity also has transformative tendencies, which could produce conflict as well as cooperative outcomes (Du Plessis 2001). In other words, depending on utilisation, ethnicity could either be dysfunctional/ destructive or functional/constructive. This duality of identity is best illustrated by a measurement of ethnic identity on a spectrum ranging between hostility and symbiosis (see figure 1). Despite the widespread occurrence of violence of varying degrees in many Nigerian urban settings owing to tense conflictual relations between indigenes and settlers, a few urban social spaces have been uniquely marked by a history of productive inter-ethnic relations (cooperation, coexistence and harmony) between the diverse groups in the area. 


\section{Figure 1: Measurement of Identity}

\begin{tabular}{|c|c|c|c|c|c|c|}
\hline Hostility & Rivalry & Discord & Indifference & Cohesion & Altruism & Symbiosis \\
\hline $\begin{array}{c}\text { Other is } \\
\text { an enemy } \\
\text { (anti-self) } \\
\text { Mutual } \\
\text { antagonism }\end{array}$ & $\begin{array}{l}\text { Other is a } \\
\text { competitor } \\
\text { and } \\
\text { object of } \\
\text { fulfilment } \\
\text { of self- } \\
\text { interest }\end{array}$ & $\begin{array}{l}\text { Other is an } \\
\text { opponent } \\
\text { due to goal } \\
\text { and interest } \\
\text { incom- } \\
\text { patibility }\end{array}$ & $\begin{array}{l}\text { Other and } \\
\text { self are } \\
\text { of no } \\
\text { significance } \\
\text { to each } \\
\text { other }\end{array}$ & $\begin{array}{l}\text { Self is } \\
\text { part of a } \\
\text { conceptual } \\
\text { group } \\
\text { Common } \\
\text { good } \\
\text { recognised }\end{array}$ & $\begin{array}{c}\text { Self } \\
\text { identifies } \\
\text { closely } \\
\text { with the } \\
\text { other }\end{array}$ & $\begin{array}{l}\text { Other is } \\
\text { extension } \\
\text { of the } \\
\text { self }\end{array}$ \\
\hline $\begin{array}{r}\text { NEG } \\
\text { (loss, ex } \\
\text { insecur } \\
\text { - Con }\end{array}$ & $\begin{array}{l}\text { TIVE IDE } \\
\text { lusion, dep } \\
y \text {, and symb } \\
\text { lict - Disinte } \\
\text { - Exclusion }\end{array}$ & $\begin{array}{l}\text { ITY } \\
\text { al, fear, } \\
\text { ic use) } \\
\text { ation }\end{array}$ & & \multicolumn{3}{|c|}{$\begin{array}{l}\text { POSITIVE IDENTITY } \\
\text { (belonging, inclusion, sharing, safety, } \\
\text { abstract security, instrumental to } \\
\text { material interests) } \\
\text { - Cooperation } \text { - Integration } \\
\cdot \text { Inclusion }\end{array}$} \\
\hline
\end{tabular}

Source: Adapted from Cronin 1999:13

This paper explores the historical sociology of inter-ethnic (indigene-settler) relations in Enugu city, south-eastern Nigeria, since the end of the civil war. The idea is to identify, interrogate and explain the factors responsible for cooperation, coexistence and harmony in inter-ethnic relations between the Igbo (indigenes) and the 'settlers' in the city, and to underline the significances of their experiences in ethnic conflict management. This achievement is even more noteworthy in the post-civil war period, due to the negative effects of the civil war on ethnic relations in the country, especially between the Igbo and the current settlers in the city.

\section{Setting and scope of the study}

Enugu city has been a major and well-known urban, coal-mining and commercial centre since its foundation in 1915. 'Enugu', which means 'Hill Top' (or 'top of the hill'), indicates the topography of the city - about 763 feet above sea level (Ministry of Information and Home Affairs 1972; Udo 1981). It is also euphemistically referred to as the 'Coal city' due to the significance of Coal for the city's foundation and development. Enugu was the administrative headquarters of Nigeria's Southern Provinces in 1929, and that of the defunct secessionist state of the Republic of Biafra in 1967. Enugu city had a population of about 138500 in 
1963, some 342800 in 1986, an estimate of about 465000 in 1991, and a projected estimate of 557584 in 1996 (National Population Commission 1991; Odoemene 2008).

The time scope of the study is from 1970 to 2003. The Nigerian civil war, which sharpened and reinforced ethnic divisions and mistrust in the country, ended in 1970. That conflict was, indeed, a significant watershed in the socio-political and conflict history of Nigeria and its end marked a 'new dawn' in the country's ethnic relations, especially between the Igbo and other ethnic groups. Thus, how Enugu's ethnic Igbo were able to achieve peaceful coexistence with their visitors after the 30 -month vituperative civil war between them is of significance. Additionally, 2003 marked the successful end of Nigeria's second civil rule period since the end of the civil war in 1970. It is important to the study because of the significance of the civilian dispensation on ethnic relations after fifteen consecutive years of divisive military dictatorship, which highly polarised Nigerians along ethnic lines.

\section{The peopling of Enugu}

The rise of Enugu as a modern city began with the active penetration of the area that later became Nigeria by the British colonialists in the first quarter of the twentieth century. A geological exploration commissioned in 1903 under the auspices and direction of the Imperial Institute, London, was led by Mr Albert Ernest Kitson, a British mining engineer and scientist (Imperial Institute 1941:36; Akpala 1965:241). In 1909, the exploration team came across extensive deposits of real sub-bituminous coal in Udi Ridge and Okoga areas, east of Ngwo village (Akpala 1965; Hair 1954; Ogbuagu 1961). By 1915 the colonial administration had started negotiating with the indigenes on the acquisition of lands for the establishment of a colliery and a railway, and the development of a large part of what has become the Enugu Township (Akpala 1965:336).

As soon as the land grants were secured, Mr W.J. Leck, in the company of a few other Europeans and some indigenous peoples, came to stay. These indigenous peoples were led by a certain Alfred Inoma and had come from Onitsha as labourers for the colliery (Hair 1954; Prince of Peace Volunteers 1966). Mr Leck and his group set up their abode in the area presently known as 'Coal Camp' and 


\section{Akachi Odoemene and Olufemi B. Olaoba}

these were the very first structures set up in what later became Enugu. Coal mining started by mid-1915 and a railway line linking Enugu with the coast at what later became Port Harcourt was completed by the end of 1915. This was primarily for the transport of mined coal.

A significant point to note about the development of Enugu's coal and railway industries is that they were essentially colonial projects. Again, they were developed immediately after the period when the northern and southern protectorates were amalgamated into one entity called Nigeria. Thus, the colonialists necessarily employed 'Nigerians' from a diversity of ethnic groups for work in these industries. Many more drifted to the new town in search of livelihood, as urbanism was a primary demographic pull factor at the time. Consequently, Enugu started witnessing unprecedented waves of migrants from diverse racial and ethnic origins, as well as occupational backgrounds. The stimulation this plural population gave to the town's socio-economic life engendered development and growth, and transformed the town into the only significant coal mining district in West Africa (Prince of Peace Volunteers 1966). Over time, Enugu town continued to widen in scope and became more accommodating to people from far and near (Enugu State Department of Information and Culture 1993).

The dramatic upsurge in the town's population also meant the gradual constellation and emergence of a permanent cosmopolitan and multi-cultural society. This trend was significantly altered, though, from the mid-1960s with the political crisis that engulfed Nigeria and snowballed into the 30-month ethnic-based civil war. This crisis period saw the drastic halting of Enugu's population growth; instead it witnessed the mass exit of non-Igbo persons who either fled to safer abodes or were expelled from the region by the then Biafran leadership. However, the town at the same time played host to thousands of Igbo people who had escaped the Igbo pogrom in the northern and western parts of Nigeria. For this group of urbandwelling Igbo, Enugu town was, naturally, the preferred choice destination.

The civil war period also witnessed unsteady migrations into and out of Enugu - a situation that was to continue until the end of the war in early 1970. With the end of the civil strife, the town witnessed yet another round of dramatic migration, this time mainly by dislodged peoples wanting to resettle after the dislocating civil 
war (Odoemene 2008). Though this movement naturally involved Nigerians from diverse ethnic groups, it was noted as being largely an Igbo affair (Udo 1981), unlike in previous times. Many members of the other ethnic groups were reluctant to venture into the post-civil war Igbo homeland. Again, the two industries on which the town thrived - the colliery and the railway - had literally died out, making Enugu town very unattractive for many non-Igbo migrants.

\section{Ethnic provenance of Enugu's population}

Though Enugu city tended to be communally heterogeneous right from its inception, the bulk of its population has been drawn from Igboland. As in the case of Port Harcourt, the Igbo responded enthusiastically to the new economic opportunities and alluring fascinations offered by the new city more than any other group (Wolpe 1974:25-26). They, more than any other group, found it easier - more convenient, accommodating and expedient - to migrate to Enugu city. This was for obvious reasons: same language, traditions and very similar climatic conditions. Apart from the Igbo, the next significant group in Enugu has always been the Hausa, together with their close associates (in the Nigerian context), the Fulani. These were followed by the Yoruba who were also quite substantial in the city (Okwudiba Nnoli 2005: personal communication (PC)). Members of other ethnic minorities, especially from Nigeria's Middle belt and Niger Delta regions, were equally represented in the city, though not substantially.

In 1929, ethnic groups (according to geo-political regions) in Enugu town were represented in the following proportions:

From Northern Nigeria: 2\%

From Western Nigeria: 10\%

From Eastern Nigeria: $87 \%$ (Coastal tribes, such as Calabar, etc. - 2\%; Igbo-85\%) (Hair 1954:3).

Hair (1954) also reports that though a 1945 one-man count in Enugu (the 'Dewhurst Census') did not inquire into ethnic provenances, such figures (according to geo-political regions) were calculated by the Local Authority from tax returns. The proportions were distributed as follows: 


\section{Akachi Odoemene and Olufemi B. Olaoba}

From Northern Nigeria: $3 \%$

From Western Nigeria: 5\%

Form Eastern Nigeria: 91\% (coastal tribes, Calabar etc., 4\%; Igbo tribes 63\%; south Iboland [sic], Owerri, etc., 24\%) (Hair 1954:5).

The next census (the 1953 general census) agreed fairly well with the 1945 one-man count in finding that $87 \%$ of the inhabitants were of Igbo stock, while other regions were represented in the same distributions (Hair 1954:5).

Ethnic provenance of the city's population in the early post-independence era (up to the later part of 1966) still had the distribution trends stated above as there were no major or radical alterations in this regard. However, this distribution was altered in the crisis and post-war periods, allowing for the settlement of more Igbo people in the city, in a proportion hitherto unknown (Okwudiba Nnoli 2005: PC). Though the official figures for each group in the city were not known, as subsequent national census exercises in Nigeria clearly avoided questions of ethnicity, most opinion and community leaders in the city attested to this remarkable shift in ethnic provenances of Enugu's population.

\section{Indigene-settler relations in Enugu city}

With the end of the civil war, one would have expected that the relations between the Igbo in Enugu city and the other groups who were on the 'Federal side' during the war would be anything but good. But on the contrary, the reverse was the case: Enugu has witnessed a history of enduring inter-ethnic harmony among the many diverse ethno-cultural groups in the city. This does not mean that issues of ethnic conflict and tension did not occur among the groups' members, but they were carefully managed and handled to have productive ends for the overall benefit of the city and its inhabitants, indigenes and settlers alike. This achievement has, however, not been without enormous challenges for the people.

In the social life of Enugu, ethnic origins were often of great importance in everyday life, though these were, sometimes, not taken into deep consideration. In ordinary conversation, one was often apostrophised as 'Yoruba,' 'Bini', 'Igbo', 'Hausa,' 'Fulani' 
and so on, and ethnic origin was often cited in describing personality in the city. Similarly, a large proportion of the quips in conversation between and/or among Enugu residents turned on the qualities and defects attributed to each person by reason of his/her ethnic origin. Though there were no violent conflicts among the ethnic groups in the city, this is not to suggest that there were no moments of upset or provocation. Indeed, provocations were easily stirred up among the groups by derogatory stereotypes and mindsets about one another.

Responses from members of diverse ethnic groups in the city to questions relating to thoughts about one's group and 'the others' showed that ethnic stereotypes remained very strong. The responses from each group's members were closely similar because they reflected not varying individual experiences, but age-long stereotypes - sometimes disparaging stories, sayings and notions - which have been passed down over the years. Most of these stereotypes about 'the other' were found to be historically inaccurate, but have been kept 'alive' over the years and moved on to different generations like oral traditions. Similarly, each ethnic group member interviewed had a belief in the intrinsic superiority of his/her own group over others. This is not surprising. As Byaruhanga (1999) observes, it is assumed by the members of an ethnic group that their values, achievements, goals, organisation or even physical structures are better, while at the same time they are holding others' ethnic qualities to be inferior and not to be preferred. This sometimes informs the dislike (or hatred in some extreme cases) and contempt for the other group (s), and is the root of prejudices, and eventually, stereotypes.

Generally, it was also observed that the non-Igbo ethnic groups were somewhat less critical of one another, as though their aggressiveness was essentially crystallised around the Igbo. This could be as a result of the over-bearing Igbo dominance in almost all affairs in Enugu city, which could have made the other groups more critical of them, while being lenient to one another. Another point to note is the effect of religion on ethnic relations in the city. As has been observed elsewhere, 'religious unity causes ethnic differences to disappear' (UNESCO 1974:99). In Enugu city, Islam, in particular, weakened the spate of ethnic antagonism among the Hausa, the Fulani and most of the Yoruba settlers. Similarly, marriages between people of these ethnic groups, unlike with the Igbo, were all the easier since Islam included them all. 


\section{Akachi Odoemene and Olufemi B. Olaoba}

In terms of ethnic violence, there were very few instances of aggression, and only one major case of overt violence in the city since 1970. Surprisingly, it was one in which a Hausa man (a settler) killed an Igbo man (an indigene) at the 'Artisan Market' in late 2003. As one would ordinarily expect, violence by the Igbo against the Hausa was to ensue, but was prevented by the timely intervention of the state and the social networks of the ethnic associations, whose members were affected (Baba Ali; Haruna Sule; Okwudiba Nnoli 2005: PC). Indeed, there were other intermittent, but not frequent, cases of bitter conflicts between Fulani herdsmen and local farmers living in the outskirts of the city. None of these, however, resulted in hostilities, as they were always amicably resolved by the authorities and networks of the ethnic associations affected (Umar Sambo; Yesuf Sambo 2005: $\mathrm{PC})$.

In all, despite the challenges of interrelations that confronted indigenes and settlers in the city, they learnt to, and did, coexist and cooperate in many spheres of endeavour. Almost all the respondents, including settlers in the city, attested to the positive inter-ethnic relations between the two segments. These candid expressions by one of the groups' leaders are revealing and representative of the general opinion of the city's diverse residents:

We do not have any problems with the people [hosts] except minor issues... We all work together; whether Yoruba, Igbo, Fulani or Hausa... We attend each other's festivals and occasions when invited. We also intermarry... We monitor situations closely and manage conflicts that arise. They [indigenes] have their leaders who are committed to peace, so we work hand-in-hand with them to ensure peace in the town... If there is any kind of problem [with one of us], they [the indigenes] come to us to report the problem and we call our people to order, and vice versa. Since I came back here in 1970 till date, there has never been any case of violence between us [settlers] and the hosts, or any other group. We are very happy with the situation here in Enugu (Baba Ali 2005: PC).

In summary, this is not to say that inter-ethnic conflicts did not exist in Enugu city within the period of study. However, the point to note here is that the residents 
went out of their way in order to maintain peaceful coexistence among themselves, despite all conflicts, tensions and provocations. In essence, the settlers lived, worked, shared, celebrated, mourned and progressed in common with their Igbo hosts. This could be better understood against the backdrop of the Igbo traditional liking for social exclusiveness, which is based on their village-oriented political institutions, but which, uncharacteristically, did not adversely affect the indigenesettler relations in Enugu city.

\section{Ethnic harmony in Enugu city: Some explanations}

The question, thus, is: what are the factors responsible for Enugu's remarkable history of enduring peace since the end of the civil war? What explains this enduring legacy of ethnic harmony in the city's history? This study was able to identify some critical factors that explain this trend, and they are here presented and argued.

\section{Insignificant number of immigrants/settlers/non-indigenes}

The number of non-Igbo immigrants in post-civil war Enugu city was too 'insignificant', unlike in the past, to warrant the feeling of socio-economic threat or dominance among the Igbo hosts. This fact removes the desire by the host to discriminate against or victimise the settlers, since they (the settlers) do not really pose a problem due to their sheer number. This 'insignificant immigrants' situation in the city was particularly so because of two basic factors. The first was the 'dying out' of the colliery and the railways - two important establishments that underlined the growth of the city - leading to the city's loss of locational importance. This sudden dwindling status of Enugu city made it seemingly 'unattractive' to immigrants (Okwudiba Nnoli 2005: PC). The second factor was the civil war experiences, which had very negative effects on the city and its social relations. Non-Igbo immigrants were, thus, weary of further migrations to Enugu due to the strained relations between the Igbo and 'the others' (Haruna Sule 2005: PC). Further buttressing this point, Abubarkar Sadiq (2005: PC) notes that:

The relationship between us [indigenes and settlers] since after the civil war has not been the same. Not that it is not cordial, but it has not been as cordial 


\section{Akachi Odoemene and Olufemi B. Olaoba}

as it used to be then [before the civil war]. The issue is that there have been lots of differences...simply because of the war... This [the war] was the problem that brought about changes in our relationship with the indigenes. And this is very regrettable.

Okwudiba Nnoli (2005: PC) also notes that:

The [Enugu's] borders are continually 'freezing up' since after the civil war... Before the war it used to be more flexible and open... When we were younger, there used to be more Hausa and many more Yoruba people. So it was really a multi-cultural and multi-ethnic community we had here then. People were moving back and front at that time... But since after the war everything got polarised. People now migrate into the city in lesser numbers, and only do so when it is absolutely necessary...

Basically, the argument here is that it is, most times, possible to disregard the relative influence and activities of a minority (or minorities) within a given spatial location, as its (or their) numerical strength would not pose a threat to the majority group, or undermine its dominative system. In other words, when the minority/minorities is/are too small and very easy to 'contain', threats of possible socio-economic dominance - the key source of livelihood and wealth - of the majority are reduced. Thus, coexistence and stability are enhanced.

\section{Groups' trade specialisations and 'non-exclusivist' competition}

The non-exclusivist nature of ethnic group competitions and the near lack of a zero-sum conflict situation among them were major factors of ethnic harmony in the Enugu polity. These have been made possible due to 'narrow specialisations' in distinct trades along ethnic lines, thus negating the need for destructive trade competitions and exclusivist conflicts. As trade and markets are meeting points for diverse ethnic and social groups, there is strong potential for a range of traderelated issues to lead to conflict. Struggles over trade control and market power, access and space also occur along commodity chains. These are particularly likely to contribute to the sparking or escalation of conflicts where underlying tensions related to structural factors were also present. 
However, despite the potential for trade to become a locus of conflict, trade specialisations along ethnic lines, non-exclusivist market relations and trading relationships have facilitated coexistence and harmony among ethnic groups. These have also helped in the reconciliation of conflicting groups and facilitation of social networks among these groups, on another level. Noting the nature of this trend, Okwudiba Nnoli (2005: PC) asserts that:

They [diverse groups] seem to have carved out different economic niches for themselves. Each group doesn't seem to be competing with others in their areas of specialty. For instance, the Igbo and Yoruba don't seem to be competing with the Hausa in the cattle trade and all its smaller units, like the making of 'Suya'l and all that, you know. And the Hausa, on their part, don't seem to be going into any other businesses that are the area of specialty of the Igbo, and so on.

Elaborating further on trade specialisations of his people, Haruna Sule (2005: PC) notes that:

The Hausa strictly face their business. The only way we [Hausa] could have problems with them [indigenes] is by trying to drag things with them. All Hausa people in Enugu do not seek employment in any place. They are all self-employed. Seeking for job is another way whereby conflict will arise... All the products we sell come from the north. So there is no problem with the indigenes. The same goes for the Fulani here in Enugu. There is no competition between us and the indigenes. Not at all.

Furthermore, without prejudice to other ethnic groups existing in the city, a close survey and examination of the main pre-occupations of the major ethnic groups' members in Enugu (see Table 1) lays credence to this fact of group specialisations.

1 Suya is a popular Nigerian meat snack and cuisine which originated from the Hausa people of northern Nigeria. It is often made of skewered and grilled beef coated with spicy peanut rub. Suya is usually served with ground pepper and onion. 


Table 1: Groups' pre-occupations and trade specialisations in Enugu
city.
\begin{tabular}{|l|l|}
\hline Hausa & $\begin{array}{l}\text { Dealers in live cattle, sheep and goats; meat sellers (including } \\
\text { 'Suya'); dealers in various perishable vegetables (from the } \\
\text { north); itinerant traders of assorted items; leather work and } \\
\text { sales; house guards and night watchmen; mobile shoemakers; } \\
\text { money changers [Bureau de Change]; truck/trailer drivers; } \\
\text { tailors (mainly of ethnic Hausa and other northern wears); } \\
\text { fresh milk hawkers (by maidens); water fetchers (by males). }\end{array}$ \\
\hline Igbo & $\begin{array}{l}\text { State civil servants (including parastatals); Federal civil servants } \\
\text { (including parastatals); primary, secondary and tertiary school } \\
\text { teachers; workers in corporate establishments (Banks, Multi- } \\
\text { nationals, Insurance, etc); general products and produce traders } \\
\text { (in markets); motor spare parts dealers; dealers in assorted } \\
\text { electronics; builders; taxi drivers; tailors (mainly of ethnic Igbo } \\
\text { and general wear); hoteliers and restaurant operators; farmers. }\end{array}$ \\
\hline Yoruba & $\begin{array}{l}\text { Federal civil servants (including parastatals); workers in } \\
\text { corporate establishments (Banks, Multi-nationals, Insurance, } \\
\text { etc); 'ethnic Yoruba restaurant' operators; builders; tailors } \\
\text { (mainly of ethnic Yoruba wear); computer accessories and } \\
\text { allied materials dealers. }\end{array}$ \\
\hline
\end{tabular}

From Table 1 above, one could decipher that apart from a few of these ethnic group members, especially the Yoruba that sought and got 'white collar jobs' in the government or corporate establishments, the majority of non-Igbo immigrants in Enugu were self-employed. Additionally, those who took up these 'white collar jobs' were still in negligible minority, when compared to the Igbo in the same occupational area. Again, the different group members almost wholly took to businesses that were not often the regular pre-occupation of the Igbo in the city. These conditions made for the non-existence of the often divisive and deadly exclusivist competition among the groups in a city.

This position is further buttressed by Barth's (1968) observation, that plural societies are most stable and enduring when the ethnic groups existing in them occupy different ecological niches, in other words, are making their living in different ways and are not competing. Jha's (2007) perspective on economic 'complementarity' between 'locals' and 'non-locals' further supports this 
argument. As Jha (2007:3-4) puts it, when ethnic groups provide complementary goods or services to one another (rather than competition between the groups), the incentive for aggression against non-locals diminishes. Thus, the greater the inter-group 'complementarity', the less incentives for ethnic violence.

In addition to this, there was the fact that most of Enugu's non-Igbo immigrants, especially the most dominant group (the Hausa), did not possess an economic aggressiveness in the pursuit of their affairs in the city. Shack (1979:6) points out that economic aggressiveness of strangers ' ... is often responsible for hostility to them by members of their host communities. This has, interestingly, been amply demonstrated by the cases of Igbo economic aggressiveness in Kano (Osaghae 1994) and also the Jos situation (Plotnicov 1971; Danfulani n.d.).

\section{Lack of upward socio-economic mobility among dominant settlers}

The visible lack of upward socio-economic mobility among most of the migrant settlers in Enugu was yet another considerable contributor to ethnic harmony. Upward socio-economic mobility among strangers (immigrants) in many societies poses a great threat to the host population (indigenes) of the locality. According to Jha (2007:4), 'the resulting wealth inequalities between locals and non-locals lead to incentives by strong locals to target non-locals with violence to seize wealth and property'. In fact, the lack of upward socio-economic mobility which is often exhibited by the ways of life of these settlers, was alluded to by most of the immigrant respondents for this study. Again, this has often been the experience in many Nigerian urban spaces over the years. However, the kind of jobs that were taken up by most dominant settlers in Enugu city (as could be seen in Table 1 above) at most times accrued meagre profits which did not permit a show of affluence. Therefore, this was positively crucial to social stability in interethnic relations in the city.

\section{Roles of ethnic unions as elixir in urban violence}

The roles of well-structured ethnic unions in the organisation and control of their group members was also identified as one other factor of enduring ethnic harmony in the city. Enugu has a plethora of such ethnic-based unions, most of which are efficiently administered (Odoemene 2008). Their contribution towards peace 


\section{Akachi Odoemene and Olufemi B. Olaoba}

and stability in the city was primarily through their conflict management and peacebuilding efforts. This is especially so since they were essentially 'a response to a conflictual situation' (Eleazu 1977:99) that existed in the urban setting. As a platform used for ensuring the socio-economic and psychological wellbeing of their various members (Osaghae 1994; Mabogunje 1976), ethnic associations usually had a large measure of control and influence on their members.

Complaints and petitions against persons of other ethnic groups were channelled to their ethnic union(s) by the aggrieved through his/her (their) own union leaders or authorities. Furthermore, the protagonist in any conflict was cautioned or punished by his/her union's leaders, while compensations (where necessary) were collectively discussed, agreed on and duly paid to victims. Most of the respondents pointed out that the invitation of the Police into inter-ethnic affairs seldom happened, as these ethnic unions were very competent to handle any kind of conflict affecting them. Haruna Sule (2005: PC) takes important notice of this:

If the Fulani (in the bush) have problems where they are, they come to me or their leader [to report] and we will send some people to go and find out what the problem is. Or we will invite the people involved through letters. For example, the type of problem they usually have is with their cattle grazing. If the cattle destroy people's farms, they [the indigenes] will complain and protest about such things and what we do is to go and meet with the Igwe [Traditional Ruler] of the affected people to settle it there outrightly.

Alhaji Ade Adeyelu (2005: PC) further buttresses this position:

Our form of peace committee is this: when we have little conflict, we come together as an association, to meet with the indigenes to settle our differences. That's what we do... Any person who causes a breach of the harmonious coexistence of the members of this city is made to make up for it, irrespective of his tribe [sic] or status through just reparation or restitution, depending on the offence committed. This is done here through his or her town union. Every tribal union [sic] here does this. And it works for us, as you can see. 
Varshney's (2002) thesis on the roles of civil society social networks in ethnic conflicts readily comes to mind here. According to Olaniyi (2003), ethnic associations and their networks fall into the category of organised civil networks. Hence, the political dynamics by which these associations mobilised their social networks, the ends they sought to advance and the means by which they pursued these ends, contributed towards ensuring peaceful coexistence between/among diverse ethnic groups in Enugu city.

\section{Non-segregated accommodation structure}

Research has shown that segregated ethnic accommodation, whether self-imposed or brought about by legislation, is a social and cultural context which elicits some kind of discrimination in actions and/or practices. Such accommodation has been shown to be conducive to marked social distancing, qualification of 'others' by means of negative determiners, and ethnic intolerance (Zaharijevski 2006:37; Adeboye 2003:304). It causes the strongest social resentment, encourages the stressing of negative qualities and the cherishing of negative stereotypes of others. Therefore, housing segregation is related to negative ethnicity and stereotypes, and often brings about bad feelings, mutual mistrust, suspicion, unhealthy rivalry and resentment (sometimes outright hatred) of 'the other' (Odoemene 2008). Indeed, residential segregation has had diverse and deep-rooted implications for ethnic relations in Nigeria. Not only did it enhance conflicts, but also accentuated the differences among diverse groups in societies where they existed. Of course, the results have always been distasteful and undesirable (Bako 1990; Albert 1993a/b; Osaghae 1994; Adeboye 2003; Olaniyi 2003).

In respect of Enugu city, settlers largely lived 'ordinarily' among their hosts (indigenes). Those who lived in what may be referred to as 'ethnic enclaves' (mainly the Hausa and some Fulani) did so in 'un-segregated neighbourhoods', strictly speaking. These enclaves were located amongst their hosts (the Igbo) and were not separate 'stranger quarters', as was the case elsewhere in the country. Thus, the ills associated with segregated neighbourhoods were largely eliminated. This arrangement in Enugu allayed the palpable suspicion and fear among hosts and strangers of what the other party was up to, or, indeed, planning for them. It 


\section{Akachi Odoemene and Olufemi B. Olaoba}

also enhanced and encouraged interaction between the groups and made for the gradual integration of strangers with the host populations.

\section{Igbo worldview on strangers, and the influence of Christianity}

The Igbo worldview on the status and treatment of strangers and the shedding of their blood on Igbo soil is another factor of ethnic harmony in Enugu. This is also intrinsically tied to the influence of Christianity, the dominant religion in Enugu area, which reinforced this worldview. Of all the breaches of social and cosmic harmony in traditional Igbo society, interrupting human life, whether one's own or another's, was about the most grave. To the Igbo, life is sacred and comes only from God. Thus, God alone has the right to interrupt it at any stage. Consequently, the society promotes social harmony among its people and its visitors/settlers, as the spilling of human blood defiles not only the murderer, but also the land on which the act was committed (Amaechi Ofodile 2005: PC). In Igbo traditional religion and cosmology, Àlà (the earth goddess) is a revered deity, whose anger could bring untold pain and anguish on the people that defile her.

Furthermore, the Igbo believe that all human beings are children of the same one big God, Chi-Ukwu. Thus, the so-called 'stranger' or 'settler' was regarded as an 'unknown relative' (Chimezie Ugbaja 2005: PC). Again, given the Igbo traditional belief that divinities often take human forms to bring some important messages to humankind, the Igbo were generally careful not to harm strangers for fear of unknowingly harming a divinity, with all the consequences that came in its trail (Amaechi Ofodile 2005: PC). Based on the foregoing, it seems, therefore, to be a widespread moral norm in Igboland that one had to be hospitable to strangers, especially when they came and stayed peacefully.

The Igbo philosophical worldview on strangers could be summarised in the following Igbo aphorisms: 'O bịara nga m, ya abiagbule m; Ya lawa, Ogwu akpọla $y a^{\prime}$ (He who comes to my place, may his coming not kill me; whenever he leaves, may he not encounter obstacles). Another very popular one says: 'Egbe bere, Ugo bere; nke si ibe-ya ebela, nku kwa ya' (Let the Kite perch, let the Eagle perch; any that does not allow the other to perch, let its wings break). These timehonoured Igbo traditional philosophies of 'Live and let live' essentially recognise the utmost importance of tolerance and peace in all human relations and as 
important ingredients for any stable political arrangement. They underscore the need for cooperation and harmony in human dealings and constrain selfish and unsympathetic relations among diverse peoples (Ndiokwere 1998:227).

It is a truism that owing to culture contacts and disruptive social change, the Igbo worldview of strangers has had some transformation in perception, meaning and practice over the years. However, it is argued that this is most likely the case for the migrant Igbo who are more affected by the vagaries of urban life, rather than those still living within Igboland and clinging to traditional Igbo lifestyle. For example, there have been instances of violent challenges by the Igbo which led to the loss of human lives. Two recent significant cases would suffice. Firstly, in 1991, there was a violent attack on the ethnic Igbo resident in Kano city by the Hausa (Kanawa) indigenes, which led to the death of several Igbo people and the displacement of several thousands. A repetition of such conflict some weeks later saw the Igbo reactionary agency violently challenging the situation, and killing several hundreds of the city's indigenes.

Secondly, in the wake of the 1999 'Sharia conflicts' in Kaduna state, some thousands of Igbo men and women were massacred by Muslim zealots in the state. As it is uncustomary for the Igbo to be buried outside of Igboland, these corpses were brought back to Igboland in trailer loads, and the spectacle triggered off violent reprisals from Igbo indigenes resident in some Igbo cities - Umuahia, Owerri, Aba, and Okigwe (but not in Enugu). In the process, a few thousands of northerners (Muslims and Christians alike) resident in these towns were killed. In other words, the argument being made from these two scenarios is that the Igbo worldview of strangers was jettisoned and the blood of strangers, which ordinarily would have been spared, was violently spilled. This happened both in the strangers' land and also in Igboland, but it was arguably triggered by the exigencies of the moment, rather than the wilful initiation of violence by the ethnic Igbo.

Christianity, the main religion practiced by the Igbo, further strengthened these traditional philosophies. In Christendom, the shedding of human blood, for whatever reason, is condemned. Revenge is also highly discouraged by the religion. Thus, the wilful killing of strangers by the Igbo is totally abhorred by their religion, while their capacity to avenge ills committed against them was also greatly 


\section{Akachi Odoemene and Olufemi B. Olaoba}

hampered by the religion. Going against these biblical injunctions would mean departing from God's presence and his favours, a much unwanted and detestable condition for the average Igbo Christian. One could very comfortably state that the southeast geo-political zone of Nigeria, the core of Igboland, has been the most peaceful in terms of inter-ethnic relations and the initiation of violence against the other since the end of the civil war. Indeed, cases of wilful initiation of violence against strangers in Igboland are rare, if they exist at all. This situation is rooted in the Igbo worldview on the status and treatment of strangers, and reinforced by their Christian beliefs.

\section{State intervention in inter-ethnic conflicts and military presence}

Since the end of the civil war, inter-ethnic conflicts in Enugu city have been carefully managed by the Enugu State government. Indeed, any ensuing ethnic conflict, or seriously publicised discriminatory treatment of strangers on ethnic grounds was treated as a matter of state security (Festus Adedayo 2005: PC). By the same token, in the only case of violence that occurred in the history of the city since the end of the civil war, the 'Artisan Market' brawl of late 2003, the Enugu State government, alongside the ethnic unions affected, acted swiftly (Festus Adedayo; Okwudiba Nnoli; Musa Abubarkar Sadiq 2005: PC). The quick intervention of these stakeholders in this matter saw the averting of imminent violence, which would have mainly targeted the Hausa and Fulani settlers in the city. This view, one of the many such opinions given, vividly captures this general perception:

...our safety in this place [Enugu city] is partly because of the concern and intervention of the government in Enugu State. Since this governor ${ }^{2}$ came to power, he has always taken our safety as of paramount concern, you understand? His agents and assistants come regularly to make sure we were safe. You see? This is also the way it has been since I came here in 1971, that is, after the war... Any time we got into problems with the indigenes, they would come to settle the problem fast... Even when there is problem in the north,

2 According to the Nigerian constitution and related decrees, a state governor, whether civilian or military, either directly or through representatives, monitors and regulates conflicts, especially ethnic conflicts, within his/her state. 
like in Kano or Bauchi, they always reassure us of our safety... and protect us (Nura Baba 2005: PC).

Another factor of social stability in Enugu city, though not popularly alluded to, or corroborated by respondents, was the presence of the military in the town. Indeed, one finds it plausible to argue so. The military estate was established in Enugu town in 1933, and by 1967 when the civil war broke out, the population of ethnic Igbo members of this estate was appreciably high when compared with those of other major ethnic groups in the country. However, the fortunes of the Igbo in the military were negatively altered with their defeat in the civil war, as the post-civil war government policies ensured their systematic marginalisation in the military (Omoruyi 1999:25, citing Ojukwu 2002:348).

This situation led to the overwhelming dominance of the military by northerners, especially the Hausa and Fulani peoples (Ojukwu 2002:347-348). The resultant effect has been the over-concentration of northerners in every military facility across the country, including the various army outposts in Enugu city. This imbalance had grave implications for conflictual ethnic relations in the city, because the bias of this outfit in conflict situations cannot be in great doubt. This is so when one takes into cognisance the establishment's configuration and ethnic provenance, especially as the military has often been indicted for complicity in inter-ethnic conflicts in the country. Thus, the realisation of the fact of such imbalances and the likelihood of bias by the army, especially when the Hausa and Fulani were affected/attacked, might have been a source of caution to Igbo indigenes in Enugu city.

Memories of such 'punitive expeditions' by the army in very recent times would only reinforce this caution. Such army campaigns in places like Odi (Bayelsa State) in November 1999 and Zakibiam and Gbagi (Benue State) in October 2001, were still very fresh and unpleasant. Of course, no sane society would want to be caught up in such an imminent military debacle, should the situation arise. Thus, the mere existence of the heavily Hausa/Fulani-dominated army estate in Enugu city was a notable factor of harmonious inter-ethnic relations in the city. 


\section{Akachi Odoemene and Olufemi B. Olaoba}

\section{Conclusion}

Though Enugu's case might not be a very perfect example of ethnic harmony and coexistence, it is, nonetheless, good enough for reference purposes. It proves that, though conflicts were ubiquitous in plural societies, their constructive management could be functional, rather than dysfunctional. This achievement of peaceful ethnic relations in the city has been, to say the least, remarkable and significant. This was not only due to its comparative dimensions, but also because of the nature of the reasons for the existence of such an atmosphere in the city. These have been diverse, simple and engagingly novel. In all these, however, one underlying factor had been the earnest 'will and desire' of members of the diverse groups, here broken down into two - 'indigenes' and 'settlers' - to coexist and cooperate, and contain their differences and conflicts without recourse to violence. Enugu, however, still faced some major challenges in terms of ethnic relations. One main area of concern was the spate of violent ethno-religious conflicts in the northern parts of the country, mainly targeting the ethnic Igbo. The introduction of 'reprisal killings' in reaction to the northern situation is a point at hand. Though there have not been such reprisals in Enugu city, its further patience should not be tested, especially as it is very strategic to both the Igbo as an ethnic group and inter-ethnic relations in south-eastern Nigeria. A case in point is the recent violent ethno-religious conflicts in Jos city, Nigeria, which also underline the complexities of the indigene-settler dichotomy in the country. Indeed, Enugu city has all the socio-demographic characteristics of Jos city: colonial origins, ${ }^{3}$ cosmopolitanism and ethnic diversity, contested indigene-settler dichotomy, contested ownership of the city, ${ }^{4}$ and marked religious differences between the indigenes and the most significant settler group. Thus, Enugu city is not immune to such violent explosions as witnessed in Jos city, especially in the face of continuous provocations.

3 Indeed, both Enugu and Jos cities share some unique similarities: both were founded in 1915 by the colonialists; the former's foundation and development was based on the coal mining industry and economy, while that of the latter was based on the tin mining industry and economy.

4 Though a remote possibility in present-day Enugu city, this has been a prominent case in Jos city and could be in any other Nigerian city, including Enugu, with colonial origins and age-long histories of migrations. 
The intermittent violent skirmishes, in which the Igbo get killed, if not stemmed, could compromise Enugu's tradition of ethnic tolerance, harmony and goodwill. This situation is even more charged with the activities of the neo-Biafran Igbo mass movement and the Movement for the Actualisation of the Sovereign State of Biafra (MASSOB). This movement has been engaging with the Nigerian State in its secessionist agenda for the ethnic Igbo. With MASSOB's diverse network, mass membership and followership, ethnic colouration and locations, sentiments could be easily mobilised for reprisals against perceived ethnic enemies. These hard facts must have to be borne in mind constantly, consciously and cautiously.

\section{Sources}

\section{Personal communications}

Ade Adeyelu, 58 years, Yoruba. Chairman, Yoruba Indigenes Association, Businessman and Hotelier, Ogui, Enugu. Interviewed on Sunday, 17 July 2005.

Amaechi Ofodile, 71 years, Igbo. Retired Civil Servant, Garki Awkunanaw, Enugu. Interviewed on Sunday, 25 September 2005.

Baba Ali (Alhaji), 64 years, Fulani. Cattle dealer, Sarikin Zango of Enugu city, Garki Awkunanaw, Enugu. Interviewed on Saturday, 16 July 2005.

Chimezie Ugbaja, 52 years, Igbo. Civil Engineer and Businessman, Coal Camp, Enugu. Interviewed on Thursday, 2 February 2006.

Festus Adedayo, 41 years, Yoruba. Special Adviser to the Executive Governor on Media Matters, Government House, Enugu. Interviewed on Tuesday, 19 July 2005.

Haruna Sule (Alhaji), c. 78 years, Hausa. Sarkin Hausawa (Leader of Hausa Community) Enugu city. Coal Camp, Enugu. Interviewed on Monday, 18 July 2005.

Musa Abubarka Sadiq (Alhaji), c. 75 years, Hausa. Chief Imam of Asata Settlement Mosque, Enugu, Cattle Dealer and Professional Auctioneer, Asata Enugu. Interviewed on Sunday, 17 July 2005.

Nura Baba (Alhaji) 52 years, Hausa. Businessman, Independence Layout, Enugu. Interviewed on Monday, 18 July 2005.

Okwudiba Nnoli, 66 years, Igbo. Retired Professor of Political Science, Brick Estate, Independence Layout, Enugu. Interviewed on Friday, 22 July 2005.

Umar Farouk Sambo (Alhaji), 32 years, Fulani. Businessman, Asata Enugu. Interviewed on Friday, 15 July 2005.

Yesuf Sambo (Alhaji) 35 years, Fulani. Businessman, A Leader of the Fulani Group, Asata Enugu. Interviewed on Friday, 15 July 2005. 


\section{Akachi Odoemene and Olufemi B. Olaoba}

\section{Literature}

Adeboye, O. 2003. Intra-ethnic segregation in colonial Ibadan: The case of Ijebu settlers. In: Fourchard and Albert 2003.

Agbese, P.O. 2001. Managing ethnic relations in a heterogeneous society: The case of Nigeria. In: Mbaku, J.M., P.O. Agbese and M.S. Kimenyi eds. Ethnicity and governance in the Third World. Aldershot, Ashgate.

Akpala, A. 1965. The background of the Enugu Colliery shooting incident in 1949. Journal of Historical Society of Nigeria, 32 (4), pp. 515-538.

Albert, I.O. 1993a. Urban migrant settlements in Nigeria: A historical comparison of the Sabon Garis in Kano and Ibadan, 1893-1991. Unpublished Ph.D. thesis, University of Ibadan, Ibadan, Nigeria.

Albert, I.O. 1993b. Inter-ethnic relations in a Nigerian city: A historical perspective of the HausaIgbo conflicts in Kano, 1953-1991. Ibadan, Institut Français de Recherche en Afrique.

Bako, A. 1990. A socio-economic history of Sabongari Kano, 1913-1989. Unpublished Ph.D. thesis, Bayero University, Kano, Nigeria.

Barth, F. 1968. Ecologic relations of ethnic groups in Swat, North Pakistan. In: Cohen, Y., Man in adaptation: The cultural present. Chicago, Aldine.

Cronin, B. 1999. Community under anarchy: Transitional identity and the evolution of cooperation. New York, Columbia University Press.

Danfulani, U.H.D. n.d. The Jos Peace Conference and the Indigene/Settler question in Nigerian politics. Available at: <http://www.ascleiden.nl/Pdf/paper-Danfulani.pdf $>$ [Accessed 30 January 2007].

Du Plessis, A. 2001. Exploring the concept of identity in world politics. A paper presented at an international conference on Politics of Identity and Exclusion in Africa: From Violent Confrontation to Peaceful Cooperation, Senate Hall, University of Pretoria, South Africa, 25-26 July 2001.

Egwu, S.G. 2005. Bridging the indigene and settler divide: Challenges of peace-building in Nigeria. A paper presented at a Seminar for Opinion Leaders to Provide Inputs into Conflict Management Discourse in Jos, February 9, at Leadership Institute, GRA Jos.

Eleazu, U.O. 1977. Federation and nation building: The Nigerian experience. Devon, Arthur H. Stockwell.

Enugu State Department of Information and Culture (ESDIC) 1993. Welcome to Enugu State. Information brochure of Enugu State Government. Enugu, National Archives of Nigeria.

Fearon, J.D. and D.D. Laitin 2000. Violence and the social construction of ethnic identity. International Organization, 54 (4), pp. 845-877.

Fourchard, L. and I.O. Albert eds. 2003. Security, crime and segregation in West African cities since the 19th century. Paris and Ibadan, Karthala and Institut Français de Recherche en Afrique. 


\section{Inter-ethnic harmony in Enugu city, South-eastern Nigeria, 1970-2003}

Hair, P.E.H. 1954. A study on Enugu. Unpublished manuscript. Enugu, National Archives of Nigeria.

Ibeanu, O. and G. Onu 2001. Ethnic groups and conflicts in Nigeria: The Southeast Zone of Nigeria (Vol. 2). Ibadan, PEFS.

Imperial Institute 1941. Government assistance to Empire Mining Industry. London, Mineral Resources Department.

International IDEA 2000. Democracy in Nigeria: Continuing dialogue(s) for nation-building. Capacity-Building Series, No. 10. Stockholm, International IDEA Publications Office.

Jha, S. 2007. Maintaining peace across ethnic lines: New lessons from the past. Available at: $<$ http://www.people.fas.harvard.edu/ jha/papers/epsj2.pdf > [Accessed 2 July 2008].

Mabogunje, A.L. 1976. Cities and African development. In: Last, G.C. and A.L. Mabogunje eds. Studies in the Development of African Resources 3. Ibadan, Oxford University Press.

Mamdani, M. 1998. When does a settler become a native? Reflections of the roots of citizenship in Equatorial and South Africa. Inaugural Lecture as A.C. Jordan Professor of African Studies, University of Cape Town, Middle Campus, 13 May 1998.

Ministry of Information and Home Affairs (MIHA). 1972. Enugu (a government flyerhandbook). Enugu, National Archives of Nigeria.

National Population Commission (NPC) 1991. Nigeria population census figures. Abuja, National Population Commission.

Ndiokwere, N.I. 1998. Search for greener pastures: Igbo and African experience. Kearney, Nebraska, Morris Publishing.

Nnoli, O. 1978. Ethnic politics in Nigeria. Enugu, Fourth Dimension Publishers.

Odoemene, A. 2008. Inter-ethnic relations in Enugu city, Southeastern Nigeria, 1970-2003. Unpublished Ph.D. thesis, University of Ibadan, Ibadan, Nigeria.

Ogbuagu, Bob. 1961. Enugu - Coal Town. Nigeria Magazine, 70, pp. 28-33.

Ojukwu, C.C. 2002. Between relegation and reintegration: The Igbo nation in post-civil war Nigeria. In: Osaghae, E.E., E. Onwudiwe and R.T. Suberu eds., The Nigerian civil war and its aftermath. Ibadan, John Archers Publishers Ltd.

Olaniyi, R.O. 2003. Ethnic conflict, segregation and civil society: Metropolitan Kano in contemporary time. In: Fourchard and Albert 2003.

Osaghae, E. 1994. Ethnicity and its management in Africa: The democratization link (CASS Occasional Monograph, No.2). Lagos, Malthouse Press.

Otite, O. 2000. Ethnic pluralism and ethnicity in Nigeria (Revised edition). Ibadan, Shaneson C.I.

Plotnicov, L. 1971. Situational ethnicity in Jos. In: Melson, R. and H. Wolpe eds. Nigeria: Modernization and the politics of communalism. Michigan, Michigan State University Press.

Plotnicov, L. 1972. Who owns Jos? Ethnic ideology in Nigerian urban politics. Urban Anthropology, 1 (1), pp. 1-13. 


\section{Akachi Odoemene and Olufemi B. Olaoba}

Prince of Peace Volunteers (PPV). 1966. Enugu township: A social survey - Discovering the meaning of servanthood in an African City. Unpublished manuscript. Enugu, National Archives of Nigeria.

Shack, W.A. 1979. Open systems and closed boundaries: The ritual process of stranger relations in new African states. In: Shack, W.A. and E.P. Skinner eds. Strangers in African societies. Berkeley, Los Angeles and London, University of California Press.

Udo, R.K. 1981. Geographical regions of Nigeria. London, Heinemann.

Ukiwo, U. 2005. The study of ethnicity in Nigeria, Oxford Development Studies, 33 (1) (March), pp. 7-23.

UNESCO (United Nations Educational, Scientific and Cultural Organisation) 1974. Two studies on ethnic group relations in Africa: Senegal, The United Republic of Tanzania. Paris, UNESCO.

Varshney, A. 2002. Ethnic conflict and civil life: Hindus and Muslims in India. New Haven, CT, Yale University Press.

Wolpe, H. 1974. Urban politics in Nigeria: A study of Port Harcourt. Berkeley, Los Angeles and London, University of California.

Zaharijevski, D.S. 2006. From ethnic isolationism to openness: The prevailing model of development. Facta Universitatis: Philosophy, Sociology and Psychology, 5 (1), pp. 35-46. 